\title{
Fetal abnormality with possibility of legal termination: maternal dilemmas
}

\author{
Malformação fetal com possibilidade de interrupção legal: dilemas maternos \\ Malformación fetal con posibilidad de interrupción legal: dilemas materno
}

\section{Samira de Souza Patrício' \\ ORCID: 0000-0002-4651-2015 \\ Vitória Regina Petters Gregório' \\ ORCID: 0000-0002-9565-348X \\ Silvana Maria Pereira' \\ ORCID: 0000-0002-1925-3273 \\ Roberta Costa' \\ ORCID: 0000-0001-6816-2047}

'Universidade Federal de Santa Catarina. Florianópolis, Santa Catarina, Brazil.

How to cite this article:

Patrício SS, Gregório VRP, Pereira S, Costa R. Fetal abnormality with possibility of legal termination: maternal dilemas. Rev Bras Enferm. 2019;72(Suppl 3):125-31. doi: http://dx.doi.org/10.1590/0034-7167-2018-0234

Corresponding Author:

Vitória Regina Petters Gregório E-mail: vitoriarpg@gmail.com

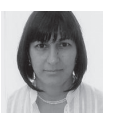

Submission: 04-11-2018 Approval: 02-07-2019

\begin{abstract}
Objective: To identify maternal dilemmas about the diagnosis of fetal abnormality incompatible with life. Method: The exploratory-descriptive qualitative method was used. Eight women participated in the research between September/2016 and January/2017 through semi-structured interviews. The data were analyzed from the thematic analysis together with the ATLAS.ti software. Results: The experiences of this study were based on suffering and emotions. The termination choice was based on personal factors of women and families, such as information on pathology and religion. Diagnoses of incompatible fetal abnormalities bring the most different feelings to those involved. It is extremely important to establish a clear communication between woman, family and interdisciplinary team in the course of gestation and delivery, with elucidation about prognosis and therapeutic possibilities. Final considerations: It was visualized the importance of embracement, communication and treatment given by the multiprofessional health team.

Descriptors: Obstetric Nursing; Gestation; Legal Abortion; Congenital Abnormalities; Nursing.
\end{abstract}

\section{RESUMO}

Objetivo: Identificar os dilemas maternos sobre o diagnóstico de malformação fetal incompatível com a vida. Método: Utilizou-se o método qualitativo do tipo exploratório-descritivo. Oito mulheres participaram da pesquisa no período entre setembro/2016 e janeiro/2017 através de entrevistas semiestruturadas. Os dados foram analisados a partir da análise temática juntamente à ferramenta de software ATLAS.ti. Resultados: As experiências deste estudo foram pautadas por sofrimento e emoções. A escolha da interrupção esteve alicerçada a fatores pessoais das mulheres e famílias, como informação da patologia e religião. Os diagnósticos de malformações fetais incompatíveis trazem os mais diferentes sentimentos aos envolvidos. É de extrema importância que se estabeleça uma comunicação transparente entre mulher, família e equipe interdisciplinar no transcorrer da gestação e parto, com elucidação quanto ao prognóstico e as possibilidades terapêuticas. Considerações finais: Visualizou-se a importância do acolhimento, comunicação e tratamento dado pela equipe multiprofissional de saúde.

Descritores: Enfermagem Obstétrica; Gestação; Aborto Legal; Anormalidades Congênitas; Enfermagem.

\section{RESUMEN}

Objetivo: Identificar los dilemas maternos sobre el diagnóstico de malformación fetal incompatible con la vida. Método: Se utilizó el método cualitativo del tipo exploratorio-descriptivo. Ocho mujeres participaron de la investigación en el período entre septiembre/2016 y enero/2017 a través de entrevistas semiestructuradas. Los datos se analizaron a partir del análisis temático junto a la herramienta de software ATLAS.ti. Resultados: Las experiencias de este estudio fueron pautadas por sufrimiento y emociones. La elección de la interrupción estuvo basada en factores personales de las mujeres y las familias, como información de la patología y la religión. Los diagnósticos de malformaciones fetales incompatibles traen los más diferentes sentimientos a los involucrados. Es de extrema importancia que se establezca una comunicación transparente entre mujer, familia y equipo interdisciplinario en el transcurso de la gestación y parto, con elucidación en cuanto al pronóstico y las posibilidades terapéuticas. Consideraciones finales: Se visualizó la importancia de la acogida, comunicación y tratamiento dado por el equipo multiprofesional de salud.

Descriptores: Enfermería Obstétrica; Embarazo; Aborto Legal; Anormalidades Congénitas; Enfermería. 


\section{INTRODUCTION}

In the world, fetal abnormalities represent an important cause for maintaining infant mortality rates, especially in developed countries where there are fewer deaths in the first year of life due to preventable causes ${ }^{(1)}$.

Among abnormalities, we can highlight as incompatible with the fetal abnormalities some neural, cardiac, abdominal closure errors, bone dysplasias and trisomies involving chromosomes 13 and 18 , these being the most frequently diagnosed ${ }^{(2-3)}$.

Such diagnoses of incompatible fetal abnormalities bring the most different feelings to those involved in this context. They become of the utmost importance to establish a clear relationship between woman, family and interdisciplinary team during the prenatal period, with elucidation about the prognosis and future therapeutic possibilities, as well as maternal well-being.

In 2016, 96,138 babies were born in Santa Catarina State; 836 died in the first year, 203 of them related to "congenital anomaly"(4).

In this context, there was in 2012 the definition of the Brazilian Supreme Federal Court (STF - Supremo Tribunal Federal Brasileiro) regarding the therapeutic anticipation of childbirth in cases of anencephaly, decriminalizing it. That was a fact historically discussed in society and in the field of health ${ }^{(5)}$. From the STF's decision, there was a discussion expansion of other cases regarding fetal abnormalities incompatible with life in the legal scope, considering its bioethical aspects ${ }^{(6)}$.

The literary search carried out at BIREME, SciELO, Lilacs and Pubmed database indexes, made possible studies related to the area of Psychology and Law. This search showed the scarcity of publications related to nursing area and other components of the multiprofessional team, when related to this theme.

It emerges as a research question: what are the dilemmas faced by pregnant women with a diagnosis of fetal abnormality incompatible with life, considering the possibility of termination or not of pregnancy?

This research is justified by relevance of the theme in women's health care scope, in addition to the impact of fetal abnormalities on infant mortality rates.

\section{OBJECTIVE}

To identify maternal dilemmas about fetal abnormality incompatible with life.

\section{METHOD}

\section{Ethical aspect}

This study is presented as a result of the macro project research entitled "Pregnant women diagnosed with severe fetal abnormality and/or incompatible with the life of the University Hospital of the Federal University of Santa Catarina: demand and therapeutic itinerary". The study followed all standards for research involving human beings defined by Resolution 466/12 of the National Health Council (Conselho Nacional de Saúde) (7), approved by the Ethics Committee of the Institution under investigation. All women signed a Free and Informed Consent
Term to participate in the research. They were identified by flower names, sequenced by the diagnosis of fetal abnormality in order to preserve anonymity of participants.

\section{Type of study}

The exploratory-descriptive qualitative method was used to make the research objective feasible. This approach makes it possible to obtain data about the studied phenomena.

\section{Study setting}

The study was carried out at the University Hospital of Universidade Federal de Santa Catarina (UHUFSC) from formal admission of women to the Women's Health Care Outpatient Clinic or entry with a confirmed diagnosis of fetal abnormality incompatible with life at the UH's Obstetric Center.

\section{Study participants and data collection}

Approaches to research participation occurred in two ways. Pregnant women embracement was done in conjunction with the multiprofessional team at the Outpatient Clinic. The research was then presented to pregnant woman and they were invited to participate in the study. Another method used came from an approach of nursing area from the Obstetric Center with women hospitalized due to fetal abnormality incompatible with life for gestation termination (legal termination /vaginal delivery/cesarean section).

The meetings followed a semi-structured interview held at a place and time suggested by pregnant women. They occurred in a reserved space at the UFSC's UH. Inclusion and exclusion criteria were established for greater homogeneity of the data. Pregnant women over 18 years of age, with diagnosis of incompatible fetal abnormality with life, performed through ultrasonography, were included in the study. Pregnant women with fetal abnormality incompatible with life were excluded from this study as since the first appointment, they did not attend the follow-up at the UH-UFSC's Outpatient Clinic.

Nine women met the inclusion criteria and were selected between September 2016 and January 2017. Of these, eight women accepted to participate in the study. This was intentional sampling based on semi-structured interviews.

Interviews were carried out by one of the researchers of the study and recorded with duration of approximately 20 minutes. All interviews were later transcribed in full.

\section{Data analysis}

For data analysis, the thematic analysis ${ }^{(8)}$ was used together with the ATLAS.ti software. This software handles large and large amounts of documents, notes and multimedia files, to identify and disseminate women through categorization of data and use of keywords.

It is a permanent process involving continuous reflections on data, that is, data analysis was conducted together with data collection.

Thus, interviews were transcribed shortly after their collection, data were organized and analyzed, according to this method of analysis consisting of three phases: $1^{\text {st }}$ - Pre-analysis; $2^{\text {nd }}$ - Exploration of the material; $3^{\text {st }}$ - Treatment of the results obtained and interpretation. 
In the pre-analysis, the choice of documents analyzed and resumption of the study objective was carried out. The operation of this stage occurred through ATLAS.ti, with the construction of a project called hermaneutic unit. This was composed by the set of all the interviews. Each of the interviews was inserted in ATLAS. ti as a primary document.

Exploration of the material is the classification operation that aims to reach the core of understanding the text, and units that contain raw data aggregated by characteristics related to contents, delimiting thematic categories. It seeks the classification of elements according to similarities and differentiations, with later regrouping according to common characteristics. Thus, cuts were made in the relevant sections of the interviews, called quotations in ATLAS.ti tools. The detailed analysis was carried out with the identification of registration units with the coding tool of ATLAS.ti, relating them to quotations with the same meaning. The coding process generated the thematic categories with the families tool.

Finally, treatment of results and interpretation consisted in the stage of analysis of empirical data based on theoretical foundations, revealing the studied phenomenon. At this stage, ATLAS.ti collaborated with the construction of networks, assisting in the visualization of thematic categories.

Thus, the results were organized into five categories: Diagnosis of Fetal Abnormality Incompatible with life; Possibility of either terminating or not with the gestation; Judicial authorization request for legal termination; Pregnancy termination; Assistance from the multiprofessional health team.

\section{RESULTS}

Women participating in this study had a mean age of 33 years. Regarding schooling, four had completed tertiary education and the others had alternated between elementary and middle school. They all lived with their partner for at least six months. Of these, four were primigravidae and the other was multipara. Regarding the region of residence, three pregnant women lived in the macroregion of Santa Catarina South and five in the macro-region of "Great" Florianópolis. Gestational age at which fetal abnormality was detected ranged from 15 to 37 weeks. Abnormalities diagnosed and involved in this study are presented in Table 1.

Table 1 - Number of participants according to the abnormality diagnosed, Florianópolis, Santa Catarina, Brazil, 2017

\begin{tabular}{lc}
\hline \multicolumn{1}{c}{ Abnormalities diagnosed } & $\begin{array}{c}\text { No of participants } \\
\text { (n) }\end{array}$ \\
\hline Anencephaly & 03 \\
Patau syndrome & 01 \\
Multiple Abnormalities (Acrania / Gastroschisis / & 01 \\
Encephalocele / Cluboot) & \\
Limb Body Wall Complex & 01 \\
Bilateral Kidney Abnormality with Adramnia & 01 \\
Occipital Encephalocele & 01 \\
\hline
\end{tabular}

Of the interviewees, five opted for legal termination, but three were in accordance with the legislation in force due to the diagnosis of anencephaly. Two filed a court order, where only one had a favorable opinion for the performance.
Next, we present the categories that emerged from the data analysis:

\section{Diagnosis of Fetal Abnormality Incompatible with life}

The news was a shock and resulted in a variety of feelings/ emotions, among the most mentioned are despair and feelings of worthlessness, being expressed in the form of crying, sadness and doubts in the face of ignorance of diagnosis, pathology and denial of the news.

At the time, there was no reaction, then he realizes [...] Yeah, I was shocked at the time and then I started crying [...] At first I felt groundless, I could not accept. (Alstroemeria - Anencephaly)

We were very shocked because we were not even going to do this ultrasound. [...] First of the diagnosis, which we did not know, then we were sad, shocked and very doubtful. (Sunflower - Occipital Encephalocele)

\section{Possibility of either terminating or not with the gestation}

Women's choice in relation to the possibility of either terminating or not with the gestation was influenced by information and knowledge about the disease, religious, family and moral factors.

The three participants who obtained the confirmatory report for anencephaly, terminated gestation; and the procedure was performed between the $15^{\text {th }}$ and the $26^{\text {th }}$ week of gestation. Of these, two were Catholic and one had no religion. Of the other fetal abnormalities incompatible with life, two women chose the possibility of terminating the pregnancy through a judicial request.

With regard to religion, one declared himself without religion and another Catholic. Those who chose the termination believed that this would alleviate both the suffering of the fetus and theirs. The final decision regarding the procedure was made by the women, who counted on the support of their partners. However, they were moments of great despair and suffering.

To avoid suffering, you know? From the moment you start to feel kicking, start to feel it, it is already a connection. [...] He [referring to her husband] did not really want to influence the decision because he said it was my body. (Alstroemeria - Anencephaly)

At the first appointment here at $\mathrm{UH}$, the doctor said he would have this possibility [referring to the termination] depending on the evolution. Only he said it could be a bit difficult because the judges are conservative. (Sunflower - Encefalocele Occiptal)

The three women who chose to continue gestation also had family support and mainly religious, keeping believers in miracles. Of these women, one was Spiritist, one Evangelical and the other Catholic. In addition, they believed that it was necessary to experience this experience as a whole for personal life learning.

We wanted to believe in a miracle, so we decided not to terminate. (Azalea - Patau Syndrome)

I am against abortion in any way. I think if it happened, I had to go through it. (Blossom Tree - Limb Body Wall Complex) 


\section{Judicial authorization request for legal termination}

Obtaining judicial authorization for pregnancy termination was difficult both emotionally and bureaucratically for one of the two participants. Women felt disrespected at being forced to obtain legal leave in such a painful period, and having to face judgments about her right to decide on her life and pregnancy.

But what hurt the most was being referred to a criminal judge. I felt invaded, too embarrassed, it seemed that I was wanting to commit a crime. [...] It was very painful to go through all the procedures that we went through and in the end it did not result in anything, it was just another wear and tear in the middle of that whole hurricane that our lives have become. (Violet - Multiple abnormalities (Acrania/Gastroschisis/Encephalocele/Clubfoot)

The other interviewee, however, reported apprehension when requesting a termination, but was surprised by the care network formed to resolve the case and how quickly the judiciary presented the opinion in favor of the termination.

We thought that the judiciary would be delayed or that they would be very conservative. [...] the evolution was very bad, the Encephalocele grew [...] so we were very desperate, not knowing what to do. I thought about terminating on my own, I had even bought the pills [...] So I looked for a friend who passed the name of a private doctor, I talked to her because I wanted guidance on how to take. Hence she gave me more encouragement to seek justice. So it was really cool this network. [...] We filed with the petition on Wednesday and Sunday I was committing to make the termination. (Sunflower - Occipital Encephalocele)

Still on this issue, we can notice the lack of knowledge on the part of the health professionals on the laws already in force in Brazil, because they guided one of the women who obtained the report of Anencephaly in pregnancy, when entering the judiciary for legal termination.

He said it was anencephaly and that I would have to go to court to be able to carry out the process. [...] But later on I learned that there is law for it. (Alstroemeria - Anencephaly)

\section{Pregnancy termination}

Women who opted for pregnancy termination felt it necessary to talk about the procedure. For them, it was something that would alleviate past suffering.

Now, knowing what is going to happen I am more relieved, but at first it gave me despair. I met a doctor there [referring to a doctor in his city] and he treated us super badly, he said that even with a court order he would not do the procedure. (Alstroemeria - Anencephaly)

These same women also cited the unpreparedness of not knowing what to do after birth and not being aware of how it would occur.

[...] Not knowing what to do when the baby comes out [crying]. Of not knowing if you look dare you do not look. I did not prepare myself for that. [...] then I thought, "Wow, why did not I get him, why did not I say a prayer there?". (Sunflower - Occipital Encephalocele)

The other women had gestation termination, intrauterine death and death after birth, where one of the participants underwent total hysterectomy after cesarean because of the adhesion of the fetal abdominal organs in the mother's womb. Of these, three were referred for cesarean section and one performed induced vaginal delivery.

Two women were concerned about the risks that gestation termination might pose to their own psychic health as a result of fetal abnormality.

I'm very worried about labor. I do not like the idea of inducing labor and suffering with pain. [...] since I cannot do anything else, I'm thinking of me now. (Azalea - Patau Syndrome)

\section{Assistance from the multiprofessional health team}

According to the women's assessment of multiprofessional health care during the period of gestation and delivery, some diagnostic information could be better addressed for understanding the family through simpler communication and a sensitive approach.

Another important point found in the study was with regard to the word "infeasible", often used imperceptibly by the team to women with diagnosis of fetal abnormality incompatible with life.

Care networks used by women provided the need for information on cases and were an important link in the decision-making process.

This thing about you saying something and the other does not understand. [...] she [referring to the private doctor] came with a language that I did not know. But the person is treated as if she have established a conversation. [...] you must have a language you expect communication. There needs to be a translation. (Sunflower - Occipital Encephalocele)

The first appointment at the hospital I went home disappointed. Is that for the doctor of the hospital it is so normal to meet people with problems, which I found a little cold! I liked the health center rather than here. He [doctor of the center] referred me, was talking to me and the doctor of the hospital is so normal that I have to ask, otherwise he does not speak to me. This unfeasible word the hospital doctor spoke of is very strong. (Blossom Tree - Limb Body Wall Complex)

\section{DISCUSSION}

Experiences of this study were based on suffering and emotions. Feelings of shock, despair and anguish that women experienced when they received the diagnosis of fetal abnormality incompatible with life, followed by sense of worthlessness and denial of the news, are similar to other studies found in Brazil(9-10). This process is due to the imaginary of the perfect son confronted with the reality of an incompatibility with life. The news of a fetal abnormality can cause various problems and reactions of depression, rejection and rupture of attachment, whether transient or permanent, triggering great physical and emotional stress, where a demand for feelings becomes present ${ }^{(11)}$. 
It is important to emphasize that not always all these moments/ reactions of confrontation are experienced by all individuals involved in the process of death and dying. In the same way, their chronological order can be altered according to experiences and culture of each individual. In fetal abnormality incompatible with life, process of coping with death occurs according to the capacity of each woman and each health professional to face the new reality installed after a definitive breakdown of expectations.

Regarding the decision-making process of termination, it was observed that although all women had the support of their partners at the time of their choice, they took responsibility during the process. This question is overwhelmed by gender roles, since traditionally the responsibility for reproduction is attributed to women ${ }^{(10)}$.

Termination choice was based on personal factors of women and families, such as information on pathology and religion. Families find ways to confront the situation according to their way of looking at the world as well as internal encouragement when facing the desire to preserve life already established in the womb ${ }^{(12)}$.

Religious and philosophical beliefs function as a largely definitive aspect of women's choice of legal disruption due to cultural aspects in Brazil and a strong religious influence ${ }^{(13)}$.

In the literature, pregnant women with religious or philosophical beliefs, when diagnosed with fetal abnormality incompatible with life, decide for continuity of gestation not only for believing in the cure and acceptance of the obstacle as suffering, as for the condemnation of abortion by the majority of religions ${ }^{(12-13)}$. In contrast, in this study, it is obtained that religious women also opted for the termination, when seen the infeasibility of the fetus. This question may be related to the level of education of women, because they present a better level of education for coping with the pathology associated with scientific medical factors, disassociating religious character only. Other authors corroborate this issue ${ }^{(14)}$.

In Brazil, abortion is considered a crime against life, according to the Brazilian Penal Code, in force since 1984. However, a crime is not characterized when practiced by a doctor in three situations: when there is a risk of death for the woman caused by the pregnancy; when pregnancy is the result of a rape or if the fetus is anencephalic (STF's decision by Arrangement of NonCompliance with Fundamental Precept 54 (ADPF54), voted in 2012, which describes the practice as "early delivery" for therapeutic purpose). In these cases, the Brazilian Unified Health System (Sistema Único de Saúde) embraces the woman to carry out the legal termination ${ }^{(5,15)}$.

When analyzing the data, it was observed that in cases of judicial requests, only one of the participants was able to terminate it by legal means. Thus, a hypothesis was opened for the lack of encouragement of health professionals in the orientation given to women who wish to make the request or the lack of legal assistance, leading to the consideration of the lawyer referral in the judgment of these processes.

Permission to abort does not mean an exception to the criminal act, but an acquittal ${ }^{(5)}$. As part of a general reflection on decriminalization, would it not be absolutory to allow pregnant mothers of fetuses with other fetal abnormalities incompatible with life to have the same listening and even right?
During the survey, women protested the validity of the law with respect to their right to choose about their life and about pregnancy termination, and the fact that they had to shoulder the burden of obtaining legal leave in such a painful period. This data indicates the need for reflection on Brazilian law in termination cases due to fetal abnormality incompatible with life. Another study presented the same results ${ }^{(16)}$.

Abortion legalization in the first three months of gestation is still being discussed in the National Congress and Senate as a way to provide choice for all women. However, it is without final opinion ( $P L 5,069 / 13$ ) for religious reasons that defend the unborn child's right. This conduct is an important step in the feminist view and, if passed, will be a gain for women's right to their choices in society ${ }^{(17)}$. However, it must be observed that the public network offers the first ultrasound from 17 to 22 weeks of gestation, thus leaving the stipulated period for the procedure, in case any abnormality is found incompatible with life. Another fact is associated to the queue of waiting and delay for marking this exam via Sistema de Regulação do Sistema Único de Saúde SISReg (Unified Health System's Regulation System) ${ }^{(1)}$.

Abortion legalization would abolish the embarrassment described by interviewees in the study. It would also allow them the right to decide on anticipating the gestational outcome that, from the point of view of some, has already occurred, when abnormality's severity had been defined.

Also, data evidence lack of information on health professionals' part with respect to the current legislation that allows termination in cases of anencephaly. Bibliography confirms the practice found, leading to questions regarding professional update. For nursing professionals, this reality is linked to the non-availability of methods of Permanent Education ${ }^{(18)}$. As they are considered atypical situations within existing hospitals, compared to the number of pregnant women without serious complications, professionals do not seek sources and updates aimed at this reality in order to improve care. This fact hinders the professional embracement to confront the situation by the pregnant woman and her family.

It is important to remember that the way in which the multiprofessional team will give the information to the woman may have future repercussions, affecting its subsequent decision-making process ${ }^{(19)}$. It is essential that the woman feels welcomed and treated with care and respect, while receiving detailed information on the fetus diagnosis and procedure to terminate with pregnancy when desired.

Quality of communication between health professionals and women depends, above all, on personal perceptions and on availability of the professional to establish relations of support and embracement with the other.

In the study, different realities experienced by pregnant women were found in different contexts (Primary and Tertiary Care), demonstrating different embracements and perceptions of women in front of the multiprofessional team.

Data showed the importance of communication with those involved in the diagnosis of fetal abnormality incompatible with life by observing terms used by the communicant and how this will affect communication, giving clarity to the subject addressed. Difficulties were found in communication of health professionals such as: lack of direct dialogue for women to express their anxieties; and lack of 
sufficient information on treatment and prognosis of the pathology. The reason for these problems can be attributed to the lack of preparation of professionals to develop adequate communication with pregnant women and their families. As a consequence, there is a considerable negative impact on lives of women who receive the news of fetal abnormality incompatible with life.

It is up to the health professionals at this moment to act with respect to the decision of the woman to terminate or not the pregnancy. This theme should be approached both during professional training and in training actions of the team so that they know how to act on the problem, not losing the possibility of interacting and clarifying doubts of women, considering the subjectivity of each woman/family when planning care actions ${ }^{(19)}$. The interdisciplinary health team is also highlighted as a positive aspect, most of the time by women, as they have received help to go through this difficult experience ${ }^{(20)}$.

It was observed that gestation termination occurred because the outcome of pregnancy would result in fetal death, not because the pregnancy was undesired. Thus, it has been discussed the possibility that in cases of fetal abnormality incompatible with life, pregnancy termination should not be classified as induced abortion, either in the medical or legal area, but rather as a therapeutic premature birth. Consequently, it would not be included in the scope of legal restrictions on abortion ${ }^{(21)}$. In this context, it is important to evaluate the term used as a therapeutic premature birth, where it is only possible to be denominated after the $22^{\text {nd }}$ week of gestation or if the gestational age is unknown, with the fetus weighing more than $\mathbf{5 0 0}$ grams or longer than 16 $\mathrm{cm}^{(1)}$. Before that, the correct term used is abortion, and can be treated in cases of fetal abnormality incompatible with life as a therapeutic abortion.

Regarding the end of pregnancy, the participants questioned whether or not they should see the baby's body immediately after birth because they did not feel prepared. This reaction was especially observed in women in the first gestation, making it more difficult to experience grief in a less traumatic way.

The study's literature addresses that although this is a painful time for the woman, it is essential that the woman sees the baby and confirms the abnormalities. Thus, marking the reality of loss and a fundamental stage in the grieving process $^{(22)}$.

\section{Study limitations}

It is suggested that new studies be carried out involving health and legal professionals, companions or more participants, in order to investigate other dilemmas, as well as prenatal conducts that may influence the process of choice before legal disruption, and other possibilities in this area.

\section{Contributions for the area of nursing}

The research has relevance to Academic and Assistance Nursing, and to the community because it is a little discussed subject and with a shortage of scientific productions in Brazil. Nursing in the area ofWomen's Health Care requires great knowledge and continuous learning, aimed at the emotional, physical and social support of women, making the practice more qualified and humanized.

\section{FINAL CONSIDERATIONS}

With the study and categorization of data, it was possible to know the dilemmas experienced during pregnancy by these women and families, based on the possibility of pregnancy termination by legal means already instituted or judicial request. In this context, it was visualized the importance of embracement, communication and treatment given by the multiprofessional health team in caring for these cases.

Feelings together with family and religious context of each woman were frequently present; these could be considered the main dilemmas pregnant women diagnosed with fetal abnormality incompatible with life have gone through.

The option of certain women in relation to legal termination aims to strengthen discussions on decriminalization of abortion according to the situations presented, guiding the right of choice for physical well-being of pregnant woman who experiences this specific situation.

Finally, it is necessary to provide comprehensive and interdisciplinary care for these pregnant women, due to situations complexity experienced. The approach to legislation, coupled with comprehensive and high quality primary and tertiary care that provides effective support, can be a great help to women experiencing this.

\section{REFERENCES}

1. Ministério da Saúde (BR). Protocolos da Atenção Básica: saúde das mulheres, Brasília (DF): Ministério da Saúde, Instituto Sírio-Libanês de Ensino e Pesquisa; 2016.

2. Tessaro A. A anomalia fetal incompatível com a vida como causa de justificação para o abortamento [Internet]. 2016. [cited 2017 Dec 08]. Available from: https://bdjur.tjdft.jus.br/xmlui/handle/123456789/11574

3. Emer CSC, Duque JAP, Müller ALL, Gus R, Sanseverino MTV, Silva AA, et al. Prevalência das malformações congênitas identificadas em fetos com trissomia dos cromossomos 13, 18 e21. Rev Bras Ginecol Obstet [Internet]. 2015 [cited 2017 Dec 08];37(7):333-8. Available from: http:// dx.doi.org/10.1590/S0100-720320150005373

4. Secretaria de Saúde de Santa Catarina. Sistema de Informações sobre Nascidos Vivos (SINASC) [Internet]. 2015 [cited 2017 Jul 07]. Available from http://www.saude.sc.gov.br/index.php/pesquisar?searchword=Sistema\%20de\%20Informa\%C3\%A7\%C3\%B5es\%20sobre\%20 Nascidos\%20Vivos\%20(SINASC)\&searchphrase=all

5. Almeida JJ. Aborto de feto anencéfalo: nova perspectiva após decisão do STF. Rev CEJ[Internet]. 2014 [cited 2017 Dec 08];18(64). Available from: http://www.jf.jus.br/ojs2/index.php/revcej/article/view/1936 
6. Silva AC, Feijó AGS, Rocha AR, Almeida Neto JB. Análise das decisões judiciais de aborto de malformações fetais e a problematização do slippery slope. Rev AMRIGS [Internet]. 2012[cited 2017 Dec 10]; 56(2):175-82. Available from: http://www.amrigs.org.br/revista/56-02/ bioetica.pdf

7. Ministério da Saúde (BR). Conselho Nacional de Saúde. Resolução n 466 de 2012. Diretrizes e norma regulamentadora de pesquisas envolvendo seres Humanos. Brasília (DF): MS; 2012.

8. Minayo MCS. Qualitative analysis: theory, steps and reliability. Ciênc Saúde Coletiva. 2012;17(3):621-626. doi: http://dx.doi.org/10.1590/ S1413-81232012000300007

9. Costa LLF, Hardy E, Osis MJD, Faúndes A. Interrupção da gravidez por anormalidade fetal incompatível com a vida: a vivência de mulheres brasileiras. Questões Saúde Reprod. 2006 Apr; 1(1);92-100.

10. Bellas GO. A moralidade do aborto de fetos com mielomeningocele [Dissertação] Rio de Janeiro: Escola Nacional de Saúde Pública Sergio Arouca; 2011

11. Santos MM, Böing E, Oliveira ZAC, Crepaldi MA. Diagnóstico pré-natal de malformação incompatível com a vida: implicações psicológicas e possibilidades de intervenção. Rev Psicol Saúde [Internet]. 2014 [cited 2017 Dec 10];6(1):64-73. Available from:http://pepsic.bvsalud.org/ pdf/rpsaude/v6n1/v6n1a09.pdf

12. Ribeiro FRG, Spink M J. Rhetorical strategies in the moral controversy over legalization of abortion: the case of anencephaly in Brazil. Interface Comunic, Saude Educ [Internet]. 2012[cited 2017 Nov 12];16(40):35-49. Available from: http://www.scielo.br/pdf/icse/v16n40/ aop0712.pdf

13. Nomura RMY, Brizot ML, Liao AW, Hernandez WR, Zugaib M. Conjoined twins and legal authorization for abortion. Rev Assoc Med Bras [Internet]. 2011 [cited 2017 Dec 10];57(2):205-10. Available from: http://www.scielo.br/pdf/ramb/v57n2/en_v57n2a20.pdf

14. Mingati VS, Góes WP, Costa IG. The anencephalic fetus abortion and the constitutional issue.J Human Growth Develop [Internet]. 2012 [cited 2017 Nov 12];2(22):133-41. Available from:http://pepsic.bvsalud.org/pdf/rbcdh/v22n2/03.pdf

15. Brasil. Código de processo penal (1988). Código de processo penal. In: ANGHER, Anne Joyce.Vademecum universitário de direito RIDEEL. 27. ed. São Paulo: RIDEEL, 2018. p. 352-395.

16. Lowy I. Detectando más-formações, detectando riscos: dilemas do diagnóstico pré-natal. Horiz Antropol [Internet]. 2011 [cited 2017 Nov 12];17(35):103-25. Available from:http://www.scielo.br/pdf/ha/v17n35/v17n35a04.pdf

17. Pelizzari E, Valdez CM, Picetti JS, Cunha AC, Dietrich C, Fell PRK, et al. Characteristics of fetuses evaluated due to suspected anencephaly: a population-based cohort study in southern Brazil. Sao Paulo Med J [Internet]. 2015 [cited 2017 Dec 10];133(2):101-8. Available from:http:// www.scielo.br/pdf/spmj/v133n2/1516-3180-spmj-2013-8012608.pdf

18. Duarte DA, Melo-Almeida MG. Conhecimento dos profissionais de saúde frente ao aborto legal no Brasil: uma revisão bibliográfica. Rev Baiana Saúde Pública [Internet]. 2010 [cited 2017 Dec 05];34(2):27987. Available from: http://files.bvs.br/upload/S/0100-0233/2010/v34n2/a1798.pdf

19. Strefling ISS, Lunardi Filho WD, Kerber NPC, Soares MC, Ribeiro JP. Nursing perceptions about abortion management and care: a qualitative study. Texto Contexto Enferm [Internet]. 2015[cited 2018 Dec 10];24(3):784-791. Available http://dx.doi.org/10.1590/0104-07072015000940014

20. Rocha WB, Silva AC, Leite SML, Cunha T. Perception of health professions on legal abortion. Rev Bioética [Internet]. 2015 [cited 2017 Dec 02];23(2):387-99. Available from: http://revistabioetica.cfm.org.br/index.php/revista_bioetica/article/view/1048/1293

21. Cúnico SD, Faraj SP, Quintana AM, Beck CLC. Algumas considerações acerca da legalização do aborto no Brasil. Mudanças Psicol Saúde [Internet]. 2014 [cited 2018 Jan 16];22(1):41-7. Available from: https://www.metodista.br/revistas/revistasims/index.php/MUD/article/viewFile/4499/4353

22. López Á, Castejón O, Pérez L, Salazar A, Rodríguez G, Urdaneta J. Alteraciones morfológicas de las vellosidades placentárias asociadas a malformaciones fetales múltiples del sistema esquelético. Rev Bras Saúde Matern Infant [Internet]. 2013[cited 2017 Dec 10];13(3):207-14. Available from: http://www.scielo.br/pdf/rbsmi/v13n3/a02v13n3.pdf 